\title{
Latin American and Caribbean Countries in the Global Quest for World Class Academic Recognition: An Analysis of Publications in Scopus and the Science Citation Index between 1990 and 2010
}

\author{
Jorge Enrique Delgado ${ }^{\mathrm{a},{ }^{*}}$ and John C. Weidman ${ }^{\mathrm{a}}$ \\ ${ }^{a}$ University of Pittsburgh,USA
}

\begin{abstract}
The article investigates global participation in academic research productivity through the growth of publications from Latin America and the Caribbean (LA\&C) in two of the most prestigious bibliographic indexes, Scopus and the Science Citation Index (SCI). Data were obtained from the SCImago Journal and Country Rank and the Iberian-American and Inter-American Network of Science and Technology Indicators databases. Tables were created for the number of citable documents in Scopus, the publications in SCI, and the comparative indicators of the number of publications in SCI from LA\&C countries adjusted for number of researchers, full-time researchers, inhabitants, and national research and development (R\&D) expenditure. The countries with the highest number of publications since 1990 SCI and 1996 Scopus were Brazil, Mexico, Argentina, and Chile. Colombia shows the largest growth in research productivity over the periods studied and became in 2010 the country with the fifth highest number of publications in both indexes. Comparative indicators adjusted for numbers of researchers, population and national R\&D expenditures do not show clear differences in performance across countries. The article concludes with suggestions for the need to provide greater contextual analysis and including other bibliographic indexes and databases in order to have a fuller understanding of the reasons for particular levels of research productivity across LA\&C countries.
\end{abstract}

\begin{abstract}
Abstrak
Artikel ini bertujuan menganalisa perkembangan publikasi dari Amerika Latin dan Karibia di sistem indeks yang paling prestisius, yaitu Scopus dan Science Citation Index (SCI). Data diperoleh dari bank data Jurnal SCJ SCImago and Country Rank dan the Iberic-American and Inter-American Network of Science and Technology Indicators. Terdapat tiga tabel; satu untuk jumlah dokumen yang dikutip di Scopus, satu untuk publikasi di SCI, dan satu tabel untuk indikator perbandingan jumlah publikasi di SCI berdasarkan jumlah peneliti, peneliti full-time, keanggotaan, dan biaya riset dan pengembangan di masing-masing negara. Negara dengan jumlah publikasi tertinggi sejak 1990 (SCI) dan 1996 (Scopus) adalah Brazil, Meksiko, Argentina dan Chili. Mereka berhasil mempertahankan dominasinya. Kolombia menunjukkan pertumbuhan terbesar dan pada tahun 2010 menjadi negara kelima dengan angka publikasi tertinggi di kedua indeks. Indikator perbandingan tidak menunjukkan perbedaan yang jelas pada aspek performa. Diperlukan analisis yang lebih kontekstual untuk memahami performa setiap negara, termasuk mengkaji bank data lain untuk hasil analisa yang lebih menyeluruh.
\end{abstract}

Keywords: World Class Universities; Bibliographic Indexes; Latin America and the Caribbean; Science and Technology Studies; Scientometrics.

\section{Introduction}

In this time of a worldwide obsession with ratings and rankings of universities, countries whose higher education institutions do not make a desired list are scrambling to find ways to make it

*Corresponding author. Address: Institute for International Studies in Education, University of Pittsburgh, 5710 Wesley W. Posvar Hall, Pittsburgh, PA 15260, USA.

Email: jed41@pitt.edu. possible to gain "world class" recognition (Altbach and Balán 2007; Salmi 2009; Liu et al. 2011). The African (other than the country of South Africa) and South American continents have fared particularly poorly in this competition for status and recognition (Salmi 2009), though there has been ongoing activity in several Latin American countries (Altbach and Balán 2007). Consequently, the purpose of this article is to explore the progress of countries in Latin America and the Caribbean (LA\&C) toward improving their capacity to compete with other countries in the global academic community. We use as our primary indicator of 
national academic capacity the production of research as reflected in scientific and scholarly journal article publication.

According to authors such as Alacoque Lorenzini Erdmann and colleagues (2009) and Stefanie Haustein (2012) scientific or scholarly journals function to certify knowledge, implement quality criteria for publication, consolidate lines of research, and serve as warehouses or repositories for information of global, regional, or local relevance as well as training referees and authors in analysis and review. Journals and articles gain visibility through their inclusion in bibliographic indexes (National Committee of Indexation and Validation et al. 2006; Erdmann et al. 2009; Colciencias 2010; Delgado 2011a, 2011b). At the global level there are mainstream indexes that include all disciplines that advance through research like Scopus, published by Dutch Elsevier, and Web of Science (a combination of specialized indexes like the Science Citation Index (SCI), Social Science Citation Index (SSCI), and Arts and Humanities Citation Index (AHCI), published by Thomson Reuters from the United States (Delgado 2010, 2011a, 2011b, 2013).

Globalization is a driving force in the developing multinational trajectory of higher education research and development. From an economic perspective, globalization may be viewed as a socioeconomic system that is characterized by increases in the size, complexity, and speed of global financial transactions. Today, есоnomic growth is a process of knowledge accumulation as well as capital accumulation. At the same time, there is a rapid acceleration in the rhythm of creation and dissemination of knowledge, which means that the life span of technologies and products gets progressively shorter (Chapman and Austin 2002; Salmi 2002; Schwartzman 2002). Journal publication has been riding the globalization wave, expanding dramatically due to the advances in information and communication technologies and the open access to knowledge movement (Alperin et al. 2008; Edgar and Willinsky 2002; Willinsky 2006).

Researchers and scholars from LA\&C have traditionally faced obstacles, including lack of English language skills and of membership in international academic networks, to have articles published by prestigious international journals (Alperin et al. 2008; Borrego and Urbano 2006; Buela-Casal et al. 2006; Delgado 2010, 2011a, 2011b). Their contribution to scholarship in most research and scientific fields has been modest. However, in the last two decades, journals have experienced an impressive growth in quantity and quality (Holdom 2005; Fischman et al. 2010). In the present study, we analyze and put in national context the growth of publications from LA\&C appearing in two of the most prestigious bibliographic indexes, Scopus, and SCI.

\section{Methods}

For this article, the number of publications by country included in Scopus was obtained from the SCImago Journal and Country Rank database (www.scimagojr.com). The search included all countries from LA\&C plus Portugal, Spain, Canada, and the United States. A table was created with the country list and the number of citable documents (articles, reviews, and conference papers) for the years 1996, 2000, 2005, and 2010. The SCImago database only includes information starting in 1996. Data about the number of publications in SCI was obtained from the Iberic-American and Inter-American Network of Science and Technology Indicators database (RICYT) (www.ricyt.org). In this case, not all the (nonSpanish- and non-Portuguese-speaking) Caribbean countries were part of the database. Thus, a second table was created with the available countries for the years 1990, 1995, 2000, 2005, and 2010. Because of the differences among countries in population size, financial resources, and other factors, a third table was created with the numbers of articles in SCI by country adjusted by (1) number of researchers, (2) number of full-time researchers, (3) number of inhabitants, and (4) research and development (R\&D) expenditures.

The five countries with the largest number of publications in both Scopus and SCI (Argentina, Brazil, Chile, Colombia, and Mexico) are discussed, highlighting the structure of the science, technology, and innovation (STI) system, legislation, and main agencies and programs that help to explain the performance of each country, and analysis of the findings. The article concludes with suggestions for refining the present study as well as directions for future research.

\section{Results}

Table 1 shows the number of citable documents included in the Scopus index. Publications from LA\&C grew 37.2 percent between 1996 and 2000, 63 percent between 2000 and 2005, and 73 percent between 2005 and 2010. The total growth of LA\&C publications in Scopus between 1996 and 2010 was 287 percent, with a peak growth in the 2005-2010 period. When compared to the total growth of world publications in 1996-2010 (127.5 percent), growth of LA\&C publications was almost 2.2 times larger. In 1996, LA\&C publications were 2.2 percent of total publications in Scopus. In 2010, the proportion increased to 3.8 percent.

Within the entire LA\&C region, most countries increased the number of their publications in Scopus. However, just four countries (Brazil, Mexico, Argentina, and Chile) accounted for 82.2 percent of total publications in 1996, with Brazil being the country with the largest share (37.8 percent). This dominance increased 
slightly to 85.6 percent in 2010 for the four countries but Brazil became more dominant, increasing its share for the region to 51.3 percent. Colombia experienced the largest percentage growth in number of publications in Scopus from 1996 to 2010 (706 percent) and became the fifth largest country in total number of citable publications listed in that index. Colombia passed Venezuela and Cuba in 2010, countries whose total growth in Scopus was 100.7 percent and 139.8 percent, respectively, between 1990 and 2010. Compared to Brazil, Colombia still has 10.3 times less publications in the index.

The country with the second highest growth of publications cited in Scopus in the 1996-2010 period was Peru (440 percent), followed by Brazil (428 percent). Among the four top LA\&C countries, Argentina experienced the lowest growth in the 19962010 period (139.8 percent). When analyzing the Spanish- and Portuguese-speaking LA\&C plus Portugal and Spain (usually regarded as Iberian-America or Iberoamérica), the region contributed 4.6 percent publications to Scopus in 1996, with Spain having the largest share 47.4 percent of publications within the region. In 2010, the participation of Iberian-America to the world publications in Scopus was 7 percent, with Spain contributing with 39 percent.

Table 2 shows the number of citable documents included in SCI. Publications from LA\&C grew 54.6 percent between 1990 and 1995, 67.9 percent between 1995 and 2000, 35.2 percent between 2000 and 2005, and 68.7 percent between 2005 and 2010. The total growth of LA\&C publications in SCI between 1990 and 2010 was 491.4 percent (282.7 percent between 1995 and 2010), with a peak growth in the 1995-2000 and 2005-2010 five-year periods. When compared to the total growth of world publications in the 1990-2010 period (112 percent; 69 percent between 1995 and 2010), growth of LA\&C publications was 2.5 times larger. In 1990, LA\&C publications were 1.6 percent of total publications in SCI, while in 2010 the proportion increased to 4.5 percent. Within the region, most countries have experienced growth of their publications in SCI. However, Brazil, Argentina, Mexico, and Chile accounted for 82.9 percent of total publications in 1990, with Brazil being the country with the largest share (35.2 percent). This dominance increased to 91.8 percent in 2010 for the four countries and to 55.3 percent for Brazil. Colombia experienced the largest growth in number of publications in SCI in 1990-2010 (1,245 percent, 682 percent between 1995 and 2010) and became the fifth country in number of publications in that index. Colombia passed Venezuela and Cuba in 2010, countries whose total growth in SCI was 167 percent and 267 percent, respectively, between 1990 and 2010. Compared to Brazil, Colombia still has 12.9 times less publications in the index.
The country with the second highest growth of publications in the 1990-2010 timeframe was Brazil (831 percent), followed by Uruguay (573 percent). Among the four top LA\&C countries regarding number of citable publications in SCI, Argentina experienced the lowest growth in the 1990-2010 (261 percent) and 1995-2010 (168 percent) periods. When analyzing IberianAmerican publications in SCI, the region contributed with 3.2 percent publications in 1990, with Spain having the largest share with 48.2 percent publications within the region. In 2010, the participation of Iberian-America to the world publications in SCI was 8.4 percent with Spain contributing 42 percent.

The Scopus index includes publications in journals of all disciplines that advance scholarship through research, while SCI does not include social sciences and humanities. When comparing the growth in numbers of citable documents in Scopus (between 1996 and 2010) and of publications in SCI (between 1990 and 2010), findings are similar. Among Iberian-American countries, Spain used to publish as many documents as all countries LA\&C region combined; however, the share of publications from Spain has been slightly decreasing. On the other side, publications from LA\&C grew more in Scopus than in SCI. When asked about the inclusion of SCI and not SSCI or AHCI in RICYT, an expert from that network indicated that the production of LA\&C publications in the social sciences and humanities is very small; most researchers in those disciplines tend to publish more in local journals and languages (Spanish and Portuguese). It would be interesting to analyze the weight of the different groups of disciplines in Scopus to see if the social sciences and humanities contribute to the differences between Scopus and SCI. Another finding similar in both indexes was that Brazil, Mexico, Argentina, and Chile have slightly increased their lead with a particular growth of publications from Brazil, the lower growth of Argentinean documents, and the ascension of Colombian publications.

Table 3 shows indicators of articles in SCI adjusted for number of researchers, population, and R\&D expenditure in IberianAmerica by country in 2010. The second and third columns show the proportion of articles in SCI per 100 researchers and 100 fulltime researchers. The countries with the highest productivity (50 percent or higher) were Panama and Chile. The rest of the countries have full-time researcher productivity rates equal to or lower than 23 percent (Spain) and 39 percent (Colombia). The country with the lowest productivity in 2010 was Paraguay with 6 percent and 11 percent for both indicators. In all cases, number of fulltime as opposed to total number of researchers was related to higher overall productivity when compared to the total number of researchers (full-time and part-time personnel as well as STI graduate students). 
Table 1. Citable Documents from LA\&C, North America, and Iberian Countries in Scopus, between 1996 and 2010, by Country

\begin{tabular}{|c|c|c|c|c|}
\hline Country & 1996 & 2000 & 2005 & 2010 \\
\hline Antigua and Barbuda & 0 & 1 & 6 & 4 \\
\hline Argentina & 3,961 & 5,115 & 6,270 & 9,499 \\
\hline Bahamas & 5 & 5 & 13 & 20 \\
\hline Barbados & 40 & 34 & 67 & 69 \\
\hline Belize & 10 & 3 & 18 & 22 \\
\hline Bolivia & 64 & 67 & 135 & 214 \\
\hline Brazil & 8,414 & 13,098 & 23,208 & 44,416 \\
\hline Chile & 1,675 & 2,023 & 3,591 & 6,368 \\
\hline Colombia & 535 & 756 & 1,349 & 4,314 \\
\hline Costa Rica & 256 & 212 & 384 & 528 \\
\hline Cuba & 722 & 1,217 & 1,250 & 1,731 \\
\hline Dominica & 3 & 1 & 11 & 18 \\
\hline Dominican Republic & 34 & 29 & 39 & 51 \\
\hline Ecuador & 99 & 120 & 259 & 411 \\
\hline El Salvador & 29 & 18 & 40 & 108 \\
\hline Guatemala & 56 & 46 & 104 & 120 \\
\hline Guyana & 7 & 17 & 27 & 36 \\
\hline Haiti & 6 & 10 & 24 & 38 \\
\hline Honduras & 24 & 22 & 34 & 63 \\
\hline Jamaica & 160 & 108 & 190 & 209 \\
\hline México & 4,358 & 5,804 & 9,858 & 13,938 \\
\hline Nicaragua & 35 & 27 & 50 & 86 \\
\hline Panamá & 81 & 93 & 183 & 333 \\
\hline Paraguay & 27 & 25 & 42 & 85 \\
\hline Peru & 158 & 227 & 447 & 853 \\
\hline Saint Kitts and Nevis & 1 & 2 & 5 & 15 \\
\hline Saint Lucia & 5 & 1 & 5 & 6 \\
\hline Saint Vincent and the Grenadines & 2 & 1 & 0 & 2 \\
\hline Suriname & 5 & 5 & 12 & 10 \\
\hline Trinidad \& Tobago & 96 & 104 & 233 & 311 \\
\hline Uruguay & 249 & 331 & 516 & 838 \\
\hline Venezuela & 967 & 1,205 & 1,706 & 1,941 \\
\hline LA\&C & 22,394 & 30,727 & 50,076 & 86,657 \\
\hline Portugal & 2,514 & 3,826 & 7,269 & 13,353 \\
\hline Spain & 22,102 & 26,621 & 41,339 & 61,345 \\
\hline Canada & 39,664 & 37,952 & 58,193 & 74,188 \\
\hline United States & 312,128 & 301,249 & 371,762 & 468,596 \\
\hline World Total & $1,016,150$ & $1,106,153$ & $1,619,736$ & $2,311,989$ \\
\hline
\end{tabular}

The indicator articles in SCI per 100,000 inhabitants is the best from the RICYT database for comparisons because there is data of every Iberian-American country for the year 2010. For the other indicators, data available from some countries is from 2008 or 2009, or there is not data at all. Among the Spanish- and Portuguese-speaking LA\&C countries, Chile has the highest score in this indicator and is followed by Uruguay, Argentina, and Brazil.

\section{Country Contexts}

In this section we discuss the STI sector in the LA\&C countries with the highest number of publications in Scopus and SCI: Argentina, Brazil, Chile, Mexico, and Colombia. Included are descriptions of the governance structures and legislation, analyses of the possible factors that contribute to the growth of publications, 
and reflections on findings in this article as well as suggestions for future directions.

Table 2. Publications from LA\&C, North America, and Iberian Countries in SCI, between 1996 and 2010, by Country

\begin{tabular}{|c|c|c|c|c|c|}
\hline Country & 1990 & 1995 & 2000 & 2005 & 2010 \\
\hline Argentina & 2,343 & 3,159 & 5,121 & 5,699 & 8,469 \\
\hline Barbados & 25 & 47 & 39 & 56 & 69 \\
\hline Bolivia & 24 & 62 & 75 & 153 & 220 \\
\hline Brazil & 3,885 & 6,727 & 12,895 & 18,765 & 36,155 \\
\hline Chile & 1,220 & 1,629 & 2,282 & 3,262 & 5,162 \\
\hline Colombia & 208 & 358 & 734 & 950 & 2,798 \\
\hline Costa Rica & 146 & 177 & 223 & 335 & 456 \\
\hline Cuba & 223 & 355 & 647 & 733 & 818 \\
\hline $\begin{array}{l}\text { Dominican } \\
\text { Republic }\end{array}$ & 22 & 14 & 49 & 37 & 70 \\
\hline Ecuador & 52 & 94 & 136 & 234 & 350 \\
\hline $\begin{array}{l}\text { El Salva- } \\
\text { dor }\end{array}$ & 9 & 4 & 17 & 25 & 59 \\
\hline Guatemala & 49 & 57 & 64 & 96 & 133 \\
\hline Guyana & 4 & 10 & 9 & 28 & 28 \\
\hline Haiti & 11 & 7 & 12 & 47 & 38 \\
\hline Honduras & 21 & 17 & 26 & 19 & 57 \\
\hline Jamaica & 122 & 164 & 152 & 184 & 362 \\
\hline México & 1,705 & 3,261 & 5,215 & 6,807 & 10,171 \\
\hline Nicaragua & 9 & 12 & 26 & 40 & 87 \\
\hline Panamá & 148 & 126 & 162 & 180 & 424 \\
\hline Paraguay & 13 & 17 & 30 & 44 & 78 \\
\hline Peru & 163 & 177 & 228 & 407 & 766 \\
\hline $\begin{array}{l}\text { Trinidad } \\
\text { \& Tobago }\end{array}$ & 65 & 94 & 108 & 206 & 185 \\
\hline Uruguay & 107 & 201 & 351 & 470 & 720 \\
\hline Venezuela & 519 & 736 & 1,179 & 1,234 & 1,385 \\
\hline LA\&C & 11,046 & 17,072 & 28,657 & 38,729 & 65,331 \\
\hline Portugal & 951 & 1,918 & 3,608 & 6,037 & 10,855 \\
\hline Spain & 10,724 & 18,379 & 24,951 & 34,846 & 51,339 \\
\hline Canada & 30,963 & 37,516 & 38,940 & 50,091 & 61,328 \\
\hline $\begin{array}{l}\text { United } \\
\text { States }\end{array}$ & 248,647 & 303,585 & 321,668 & 375,401 & 402,073 \\
\hline $\begin{array}{l}\text { World } \\
\text { Total }\end{array}$ & 685,171 & $\mathbf{8 5 8 , 9 7 0}$ & 988,156 & $1,192,470$ & $1,450,764$ \\
\hline
\end{tabular}

Source: Iberic-American and Inter-American Network of Science and Technology Indicators [RICYT: Red de Indicadores de Ciencia y Tecnología-

Iberoamericana e Interamericana]. 2012. Bibliometric Indicators: Publications in SCI [Indicadores Bibliométricos: Publicaciones en SCI]. Buenos Aires: RICYT. Retrieved: December 12, 2012. Available online at: www.ricyt.org.

\section{Argentina}

Argentina enacted the Law 25,467 of STI in 2001. Federal and local governments have competence at regulating STI in Argentina, which is mostly developed in the public sector. The policymaking, development, and coordination functions of STI are responsibility of the Ministry of Science, Technology, and Productive Innovation that was created in 2007. There are some agencies with promotion and coordination competences at the province and municipal levels like in the province of Cordoba and the city of Buenos Aires. However, the system is mostly centralized at the national level (Organization of Iberic-American States [OEI] and RICYT 2009; Lemarchand 2010).

Table 3. Proportion of Articles in SCI regarding Number of Researchers, Population, and R\&D Expenditure in Iberian-America, 2010

\begin{tabular}{|c|c|c|c|c|}
\hline Country & $\begin{array}{l}\text { Articles in } \\
\mathrm{SCI} / 100 \\
\text { researchers }\end{array}$ & $\begin{array}{l}\text { Articles in } \\
\text { SCI/100 } \\
\text { full-time } \\
\text { researchers }\end{array}$ & $\begin{array}{l}\text { Articles in } \\
\text { SCI/ } \\
100,000 \\
\text { inhabitants }\end{array}$ & $\begin{array}{l}\text { Articles in } \\
\text { SCI/R\&D } \\
\text { expenditure } \\
\text { (US\$ mil- } \\
\text { lion) }\end{array}$ \\
\hline Argentina & 11.44 & 17.79 & 21.11 & 3.70 \\
\hline Bolivia & 10.21 & 13.36 & 2.11 & $8.35^{*}$ \\
\hline Brazil & 15.39 & 26.07 & 18.70 & 1.45 \\
\hline Chile & 54.50 & 94.88 & 30.20 & 5.69 \\
\hline Colombia & 17.35 & 39.07 & 6.14 & 4.89 \\
\hline Costa Rica & $12.35^{*}$ & $28.20^{*}$ & 9.78 & $2.72^{*}$ \\
\hline Cuba & 16.78 & N/A & 7.30 & 2.09 \\
\hline Dominican R. & N/A & N/A & 0.70 & N/A \\
\hline Ecuador & $13.11^{\dagger}$ & $23.06^{\dagger}$ & 2.41 & $2.44^{\dagger}$ \\
\hline El Salvador & 11.43 & N/A & 0.95 & 4.09 \\
\hline Guatemala & 22.46 & 36.63 & 0.92 & 7.39 \\
\hline Honduras & N/A & N/A & 0.74 & N/A \\
\hline México & N/A & 22.57 & 9.05 & 2.06 \\
\hline Nicaragua & N/A & N/A & 1.50 & N/A \\
\hline Panamá & 84.63 & 103.41 & 12.11 & 8.16 \\
\hline Paraguay & $6.23^{\dagger}$ & $11.37^{\dagger}$ & 1.20 & $5.22^{\dagger}$ \\
\hline Peru & N/A & N/A & 2.59 & N/A \\
\hline Uruguay & 22.72 & 37.20 & 21.81 & 4.52 \\
\hline Venezuela & $20.50^{*}$ & $26.87^{*}$ & 4.80 & N/A \\
\hline LA\&C & $14.75^{\ddagger}$ & $25.19^{\ddagger}$ & 8.11 & $1.85^{\ddagger}$ \\
\hline Portugal & 11.27 & 23.46 & 102.04 & 2.97 \\
\hline Spain & 22.91 & 38.12 & 109.18 & 2.65 \\
\hline
\end{tabular}

Source: Iberic-American and Inter-American Network of Science and Technology Indicators [RICYT: Red de Indicadores de Ciencia y TecnologíaIberoamericana e Interamericana]. 2012. Bibliometric Indicators: Publications in SCI [Indicadores Bibliométricos: Publicaciones en SCI]. Buenos Aires: RICYT. Retrieved: 12 December 2012. Available online at: www.ricyt.org.

${ }^{*}$ Data from 2009. ${ }^{\dagger}$ Data from 2008. ${ }^{\ddagger}$ Data estimated. N/A: data not available

An agency, the National Council of Scientific and Technical Research (CONICET: Consejo Nacional de Investigaciones Científicas y Técnicas), is in charge of implementing R\&D activities through research laboratories, centers, and institutes of its own and belonging to public universities. Two of CONICET's main functions are granting scholarships for graduate (mostly doctoral) education and managing the national system of researchers (OEI and RICYT 2009). Researchers affiliated with CONICET and public universities compete for public funding of projects that include communication of results. Similar to countries like Brazil and Colombia, Argentina has developed a journal evaluation sys- 
tem called "Basic Scientific Journal Nucleus” that consists of a list of journals that meet quality standards (Argentinean Center for Scientific and Technological Information [CAICYT] 2011). Many of those journals have been included in main indexes like Scopus and SCI. It could be assumed that it increases the possibility for researchers to publish in closer and more accessible publications but, as we have suggested in the foregoing, this might apply mainly to particular disciplines.

The findings of the present research indicated that Argentina has been and remains one of the top four LA\&C countries in number of publications in Scopus (Table 1) and SCI (Table 2). However, the growth of publications from Argentina has not been as large as other countries in the region in the last two decades. Likewise, the proportion of articles per 100 full-time and total researchers was below the regions' average in 2010. However, the analysis of publications adjusted for population and R\&D expenditures shows that Argentina performs among the top four countries (along with Chile, Uruguay and Brazil) for the former and above the average for the latter indicator (Table 3). This suggests the country has maintained a stable body of researchers and research institutions in the public sector (CONICET and public universities). Further expansion may require more work to increase private sector involvement in R\&D activities (Lemarchand 2010).

\section{Brazil}

Like Argentina, the Brazilian government has a structure at the federal and state levels to support STI. Some of the main agencies in this sector are the National Council of Science and Technology, the Ministry of Science and Technology, the National Council for Science and Technology Development (CNPq: Conselho Nacional de Desenvolvimento Científico e Tecnológico), the Research and Project Fund (FINEP: Financiadora de Estudos e Projetos), and the Coordination for Improvement of the Higher Level Personnel (CAPES: Coordenação de Aperfeiçoamento de Pessoal de Nível Superior). Brazil has emphasized graduate education: there are currently more than 2,228 masters and 652 doctoral programs (OEI and RICYT 2009; Lemarchand 2010).

In addition, to support the increasing number of researchers who need to publish scholarly work, there is a bibliographic index (Qualis) for national journals (CAPES 2008b; Erdmann et al. 2009; Nardi 2008) and funding for publications (CAPES 2008a). In Brazil, some states have played an important role at supporting and promoting the development of STI (OEI and RICYT 2009). The main one is the state of São Paulo whose STI agency, the Foundation for the Support of Research (FAPESP: Fundacão de Amparo á Pesquisa do Estado de São Paulo), in collaboration with the Regional Library of Medicine of the Pan-American Health Organization, created the Scientific Electronic Library Online (SciELO) (Delgado 2010, 2011a, 2011b, 2013; Meneghini 2002). SciELO is an Iberian-American open access full-text journal repository and index that was created to increase the visibility of researchers and journals from the region. Currently, SciELO has started to develop some collaboration with Thomson Reuters and the Index Medicus (most prestigious index in the medical sciences) to allow its collection to be included in those indexes' databases.

In this article, the volume of publications from Brazil is around half of the whole LA\&C region in both Scopus and SCI, which could be associated with the size of its population and economy. However, the performance of Brazil on indicators such as proportion of articles in SCI per 100 researchers, per 100 full-time researchers, and adjusted for R\&D expenditure is around the LA\&C average. However, the number of articles in SCI as a proportion of the population is among the four highest in the region. This could be explained by the special support that is given to the graduate education through master's and doctoral programs and the incentives to publication by CAPES (CAPES 2008a, 2008b). More research is necessary to understand how the different factors related to the development of STI interact in Brazil.

\section{Chile}

One of the most interesting cases in this article is Chile. With a population of 17.09 million (43 percent of the population of Argentina, 38 percent of Colombia, 15 percent of Mexico, and just 9 percent of Brazil, Chile has the fourth highest number of publications in Scopus and SCI, and is among the top performers in the region regarding the four indicators analyzed here (RICYT 2012). While some countries still focus mainly on science and technology, Chile develops it policy around innovation and competitiveness. Chile's president is advised by the National Council of Innovation for Competitiveness, an agency that proposes the guidelines for the National Strategy for Innovation. The Committee of Ministries for Innovation, in turn, determines the strategies and goals for the National Innovation Policy. Two government agencies, the National Commission for Scientific Research and Technology (CONICYT: Comisión Nacional de Investigación Científica y Tecnológica) and the Corporation for the Promotion of Production (CORFO: Corporación para el Fomento de la Producción) are in charge of implementing the policy by promoting and providing funding for human capital development and support of research (the former) and promotion of entrepreneurship (the latter) (Delgado 2011a; OEI and RICYT 2009). CONICYT develops several programs that could be associated with the high scores in the indi- 
cators used for the present research: creation of a culture of science and technology in the community; funding for graduate education in Chile and abroad; attracting prestigious researchers from abroad; competitive funding for research and technology projects; enhancing the installed capacity in universities and institutes to increase competitiveness of businesses; support for research groups and institutes; international cooperation; and access to scientific and technological information (OEI and RICYT 2009).

Most research institutions (universities, centers, and others) in Chile are privately managed and the government only participates by creating the legal and institutional structure and providing resources for scientific and technological activities. For instance, universities are ranked by numbers of undergraduate enrollment, professors with doctoral degrees, funded projects, and publications in journals included in the Web of Science and SciELO. Institutions receive incentives that universities use in different ways such as salary bonuses for productive professors (Delgado 2011a).

\section{Mexico}

In Mexico, government involvement in STI activities can be found at the federal and state levels. The federal government holds the main responsibilities mainly through two agencies: the General Council of Scientific Research and Technological Development and the National Council of Science and Technology (CONACYT: Consejo Nacional de Ciencia y Tecnología). The General Council establishes the policies and coordinates the actions. CONACYT is responsible for the implementation of the STI policy, which includes the consolidation of research groups and coordination of the National System of Researchers. As well as CONICET in Argentina, CONACYT has its own research centers. States also have offices specialized in promoting and coordinating scientific research; state councils do not have their own funding to support R\&D projects. Most of the $R \& D$ activities are concentrated in public and private universities, CONACYT centers and specialized centers (OEI and RICYT 2009; Lemarchand 2010).

Of particular importance about Mexico is the existence of two projects that include the Iberian-American region as a whole, Latindex and RedALyC. Developed by the National Autonomous University of Mexico Library System in collaboration with the regional countries' STI agencies (who provide the information to feed the Latindex database), Latindex is the most comprehensive directory and catalogue of scientific journals. Recently, Latindex launched the Portal of Portals (http://www.latindex.ppl.unam.mx) that includes the most representative databases and repositories of the region (Cetto and Alonso 1999; Cetto and Hillerud 1995; Cetto et al. 2010; Delgado 2011a, 2011b, 2013). In contrast, RedALyC is a repository and index of journals mainly in the social sciences and humanities. Managed at the Autonomous University of the State of Mexico, RedALyC was created as a response to the lack of access by social scientists to reliable literature in the Spanish language (Aguado 2010; Aguado et al. 2008; Delgado 2010, 2011b; RedALyC 2008).

Considering that Mexico is the second most populated country in LA\&C (112.3 million in 2010), it could be expected that its number of publications would be closer to Brazil, the most populated (193.3 million in 2010) (RICYT 2012). However, total numbers of Mexican publications in Scopus and SCI are closer to Argentina. This is reflected in the indicator articles in SCI per 100,000 inhabitants (Table 3). Articles included in Scopus and SCI are not comprehensive measures of where Mexican researchers publish their work, but they do suggest trends at a particular time. This applies to the other countries as well. In fact, an article published by Jorge Enrique Delgado (2011b) about open access journals in LA\&C shows that the repository RedALyC tends to have more journals from Mexico. Future research might explore whether Mexican (and LA\&C) authors tend to publish more in local journals in local languages or in particular disciplines. Such a study should be comprehensive, including Scopus, Web of Science, SciELO, RedALyC, as well as other relevant indexes, databases, and repositories.

\section{Colombia}

Despite (or perhaps due to) starting with low production of articles as represented in Scopus (1996) and SCI (1990), Colombia experienced the largest growth in the number of publications in both indexes (Tables 1 and 2). When contrasting this measure with other variables, Colombia showed important performance with respect to number of full-time researchers (Table 3).

The governance and development of STI in Colombia is mostly found at the national level with two agencies that are in charge of policy-making, management, and coordination: the National Council of Science and Technology and Colciencias, and agency that recently was upgraded from an Institute to the Department of Science, Technology, and Innovation (Law 1,286 2009; OEI and RICYT 2009). Important in the rise of Colombian publications and other STI indicators are the programs to support and rank research groups and centers as well as tie research funding to them. In addition, in the mid-1990s Colciencias created the National Bibliographic Index-Publindex. In the early 2000s, Publindex became a ranking of national scientific journals and a validation system for international journals. In 2002, the Colombian government enacted Decree 1,279 that linked salaries of professors from public universities to Publindex rankings. For a journal to be in the 
top category of Publindex (A1), it must be included in two or more mainstream indexes like SCI and Scopus (Charum 2004; Charum et al 2002; Gómez et al. 1998). Unlike Chile that only recognizes Web of Science and SciELO, Colombian Publindex also recognizes Scopus as one of the main indexes. Professors from public universities in Colombia receive points for publication in indexed journals that become salary increases for life. In the case of private universities, several Colombian higher education institutions have adopted mechanisms similar to other LA\&C countries granting one-time salary bonuses to professors for publications (Delgado 2011a).

Another factor that could increase the number of publications in Colombia is the recent enactment of the Law $(1,592)$ that allocates oil royalties evenly among the departments. Those funds will be managed by the department secretaries of STI and will be used in R\&D projects (El Tiempo 2012).

\section{Journals from Other Countries}

The share of publications from Cuba and Venezuela changed between 1990 SCI or 1996 Scopus and 2010. In both countries, the number of documents grew but at a lower rate than other countries. In the case of Cuba, it could be hypothesized that factors such as the current stagnation of the economy, the lower demographic growth, and the aging population could be associated with a slow growth of this and other scientific outcomes (Mesa Lago 2012). It seems that the recent reforms established by President Raúl Castro are aimed at generating new dynamics and revitalizing the country.

In contrast, Venezuela's change in policy toward a more socially-oriented focus has also had an effect on scientific and scholarly publications. Funding that used to be provided for the publication of scientific journals and the one-time salary bonuses that professors used to receive for their publications are disappearing as the current government shifts to funding projects that focus on solving local needs (Delgado 2011a).

There is also a group of countries that have contributed little to the publications in Scopus and SCI. They include countries from Central America (with the exception of Panama and Costa Rica), non-Spanish-speaking Caribbean, and Paraguay, Bolivia, and Ecuador. Interesting to analyze in future studies would be the high performance of Uruguay and the low performance of Peru.

\section{Reflections}

The present study has been useful to learn about STI outcomes (specifically publications in the Scopus and SCI indexes) from LA\&C by country and as a region. Progress away from the coloni- al heritage of Portugal and Spain has also been shown in the analysis. However, most attention was put on the Spanish- and Portuguese-speaking countries, thereby risking exclusion of Englishand French-speaking countries in the region. In addition, some comparisons also seem to privilege higher performers that also happen to be larger and possibly richer countries. In a few cases, countries relatively small like Chile and Uruguay show outstanding performance, but still competition is unbalanced.

LA\&C research productivity has grown as reflected in both Scopus and SCI indexes at a rate that is higher than the world average but, nonetheless, its share is still modest. We did not consider how much and in what way those indexes have grown by adding new publications. This is particularly important because indexes like SCI and the Index Medicus have been criticized for being language and geography exclusive. These indexes do not necessarily represent the universe of publication worldwide and are somehow endogamous, which is often and paradoxically criticized about journals from developing countries. With the emergence and growing popularity of regional initiatives like SciELO, Latindex, and RedALyC, the publishers of often called mainstream indexes included in the Web of Science have created "expanded" versions to accommodate journals from other latitudes but without including them in the core lists. The campaign that the Web of Science counterpart, Scopus, has done to penetrate LA\&C is also of interest. Scopus has grown fast by incorporating a diverse group of journals in different disciplines and from different countries.

Future studies on scientific and scholarly publications should be more comprehensive and include, besides Scopus, all the indexes that are part of the Web of Science, plus regional initiatives like Latindex, SciELO, RedALyC, LiLACS (LA\&C literature in health sciences) and CLACSO (social sciences and humanities). In addition, it would be useful to contrast the growth of publications in indexes with the growth of scientific journals to see whether or not newer journals reflect different disciplinary perspectives and approaches.

Beyond the questions about the amount of participation of LA\&C in the global scientific arena, it is essential to ask for the relevance of knowledge. What happens with what is published? Is the competition over publication in journals included in rankings to gain salary bonuses, in the case of university professors, creating a market for particular types of academic publications? How are disciplines growing and developing within this global knowledge market? Further, is anybody using the knowledge generated for something beyond accumulating and arraying statistics designed to be used for rankings rather than human or social benefit? What is the role of academia in this process? Is knowledge being used in teaching? How is the general population benefitting from 
the exponential growth of publications? These are some of the questions that require further attention, study and analysis.

\section{References}

Aguado, Eduardo. 2010. Bibliometrics, Evaluation, and Development: Iberic-American Scientometric Atlas RedALyC-Fractal [Bibliometría, Evaluación y Desarrollo: Atlas Cienciométrico de Iberoamérica Redalyc-Fractal (ACibrf)]. Valdivia, Chile: 2do. Congreso Internacional de Editores RedALyC. Available online at: $\underline{w w w}$.redalyc.uaemex.mx.

Aguado López, Eduardo, Rosario Rogel Salazar, Gustavo Garduño Oropeza, and María Fernanda Zúñiga. 2008. "RedALyC: an Alternative to the Scientific Knowledge Distribution Asymmetries” [Redalyc: una Alternativa a las Asimetrías en la Distribución del Conocimiento Científico]. Ciencia, Docencia y Tecnología XIX (37): 11-30.

Alperín, Juan Pablo, Gustavo Fischman, and John Willinsky. 2008. "Open Access and Scholarly Publishing in Latin America: Ten Flavours and a few Reflections.” Liinc em Revista 4 (2): 172-185. Available online at: www.ibict.br/liinc.

Altbach, Philip G., and Jorge Balán, eds. 2007. World Class Worldwide: Transforming Research Universities in Asia and Latin America. Baltimore, MD: Johns Hopkins University Press.

Argentinean Center for Scientific and Technological Information [CAICYT: Centro Argentino de Información Científica y Tecnológica]. 2011. History of the Basic Scientific Journal Nucleus [Historia del Núcleo Básico de Revistas Científicas]. Buenos Aires: CAICYT. Available online at: www.caicyt.gov.ar.

Borrego, Ángel, and Cristóbal Urbano. 2006. "Evaluation of Social Sciences and Humanities Journals” [La Evaluación de Revistas Científicas en Ciencias Sociales y Humanidades]. Información, Cultura y Sociedad 14: 11-27.

Buela-Casal, Gualberto, Pandelis Perakakis, Michael Taylor, and Purificación Checa. 2006. "Measuring Internationality: Reflections and Perspective on Academic Journals." Scientometrics 67 (1): 45-65.

Cetto, Ana María, and José Octavio Alonso, eds. 1999. Scientific Journals in Latin America. México: International Council of Scientific Unions, Universidad Nacional Autónoma de México, Consejo Nacional de Ciencia y Tecnología, Fondo de Cultura Económica.

Cetto, Ana María, and Kai-Inge Hillerud. 1995. Scientific Publications in Latin America. México: International Council of Scientific Unions, UNESCO, Universidad Nacional Autónoma de
México, Academia de investigación Científica, Fondo de Cultura Económica.

Cetto, Ana María, José Octavio Alonso-Gamboa, and Saray Córdoba. 2010. "Ibero-American Systems for the Dissemination of Scholarly Journals: a Contribution to Public Knowledge Worldwide.” Scholarly Research Communication 1 (1): 1-16.

Chapman, David W., and Ann E. Austin, eds. 2002. Higher Education in the Developing World: Changing Contexts and Institutional Responses. Westport, CT: Greenwood.

Charum, Jorge. 2004. The Construction of a National System of Indexation, The Publindex Case [La Construcción de un Sistema Nacional de Indexación, el Caso de Publindex]. Convergencia 11 (35): 293-309.

Charum, Jorge, Carlos Murcia, Diana Usgame, and Adriana Silva. 2002. The Search for Visibility through Quality: the Challenge for the Editor [La Búsqueda de la Visibilidad a través de la Calidad: el Reto del editor]. Calidad de la Educación Superior 2. Bogotá: Instituto Colombiano para el Fomento de la Educación Superior-ICFES.

Colciencias. 2010. Guide. Permanent Service for Colombian Science, Technology, and Innovation Journal Indexation. National Bibliographic Database. National Bibliographic Index Publindex [Documento Guía. Servicio Permanente de Indexación de Revistas de Ciencia, Tecnología e Innovación Colombianas. Base Bibliográfica Nacional - BBN. Índice Bibliográfico Nacional Publindex - IBN]. Bogotá: Colciencias.

Coordination for Improvement of the Higher Level Personnel [CAPES: Coordenação de Aperfeiçoamento de Pessoal de Nível Superior]. 2008. Evolution of Capes-Brazil Scholarships 1995-2008 [Evolução das Bolsas de Estudo Capes - Brasil, 1995 a 2008]. Table. Brasilia: CAPES.

CAPES. 2008. WebQualis 3.0. Application to Classify Vehicles for the Dissemination of Scientific Production of the Brazilian Graduate Programs [WebQualis 3.0. Aplicativo para a Classificação dos Veículos de Divulgação da Produção Científica da Pos-Graduação Brasileira]. Brasilia: Fundação CAPES.

Delgado, Jorge Enrique. 2010. "Trends in the Publication of refereed Journals in Spanish- and Portuguese-Speaking Latin America." Comparative and International Higher Education 2 (2): 43-49. Available online at: www.higheredsig.org/cihe.

Delgado, Jorge Enrique. 2011a. Journal Publication in Chile, Colombia, and Venezuela: University Responses to Global, Regional, and National Pressures and Trends. Doctoral dissertation. Pittsburgh: University of Pittsburgh, School of Education. Available online at: etd.library.pitt.edu/ETD/available/etd$\underline{08102011-124121 .}$. 
Delgado, Jorge Enrique. 2011b. "Role of Open Access in the Emergence and Consolidation of Refereed Journals in Latin America and the Caribbean.” Educación Superior y Sociedad 16 (2). Available online at: ess.iesalc.unesco.org.ve.

Delgado, Jorge Enrique. 2013, forthcoming. “Open Access Dental Scientific Journals in Iberic Countries, Latin America, and Colombia.” Colombia Médica 44 (Special issue).

Economy Section El Tiempo [Sección Economía El Tiempo]. May 4, 2012. Reform to Royalties is Ready to Start Functioning [Reforma a regalías ya está lista para que empiece a operar]. El Tiempo. Available online at: www.eltiempo.com.

Edgar, Brian D., and John Willinsky. 2010. "A Survey of the Scholarly Journals Using Open Journal Systems.” Scholarly and Research Communication 1 (2): 1-22.

Erdmann, Alacoque Lorenzini, Maria Helena Palicci Marziale, Mavilde da Luz Gonçalves Pedreira, et al. 2009. "Evaluation of Scientific Periodicals and the Brazilian Production of nursing Articles.” Revista Latino-Americana de Enfermagem 17 (3). Available online at: www.eerp.usp.br/rlae.

Fischman, Gustavo E., Juan Pablo Alperín, and John Willinsky. 2010. "Visibility and Quality in Spanish-language Latin American Scholarly Publishing.” Information Technologies \& International Development 6 (4): 1-21.

Gómez, Yuri Jack, Juan Carlos Andukia, and Nadeyda Rincón. 1998. "Colombian Scientific Periodical Publications" [Publicaciones Seriadas Científicas Colombianas]. Interciencia 23 (4): 208-217.

Haustein, Stefanie. 2012. Multidimensional Journal Evaluation. Analyzing Scientific Periodicals beyond the Impact Factor. Berlin: Walter de Guyter.

Holdom, Shoshannah. 2005. "E-Journal Proliferation in Emerging Economies: The Case of Latin America.” Library and Linguistic Computing 20 (3): 351-365.

Lemarchand, Guillermo A., ed. 2010. National Science, technology, and Innovation Systems in Latin America and the Caribbean [Sistemas Nacionales de Ciencia, Tecnología e Innovación en América Latina y el Caribe]. Montevideo: UNESCO, Oficina Regional de Ciencia para América Latina y el Caribe.

Liu, Nian Cai, Qi Wang, and Ying Cheng, eds. 2011. Paths to a World-Class University: Lessons from Practices and Experiences. Global Perspectives on Higher Education, 23. Rotterdam: Sense Publishers.

Meneghini, Rogerio. 2002. "SciELO (Scientific Electronic Library Online) Project and the Visibility of 'Peripheral' Scientific Literature.” Quim Nova 26 (2): 156.

Mesa Lago, Carmelo. 2012. Cuba in Times of Raúl Castro: Economic and Social Reforms and their Effects [Cuba en la Era de
Raúl Castro: Reformas Económico-Sociales y sus Efectos]. Miami: Colibrí.

Nardi, Roberto. 2008. "Some Reflections about Criteria used to Characterize and Evaluate Academic Production in the Field of Science Education: Data about journal Ciência \& Educação” [Algumas Reflexões sobre Parâmetros Utilizados para Caracterização e Avaliação da Produção Acadêmica na Área de Educação em Ciências: Dados Sobre a Revista Ciência \& Educação]. Tecne, Episteme y Didaxis Special issue: 47-62.

National Committee of Indexation and Validation [Comité Nacional de Indexación y Homologación], Colciencias, and Colombian Observatory of Science and Technology [Observatorio Colombiano de Ciencia y Tecnología OCyT]. 2006. Indexing and Abstract Services used in Processes of Indexation and Validation of ST+I Journals 2003-2006 [Servicios de Indexación y Resumen utilizados para los Procesos de Indexación y Homologación de Revistas Especializadas de CT+I 2003-2006]. Bogotá: Colciencias.

Network of Scientific Journals from Latin America, the Caribbean, Spain, and Portugal [RedALyC: Red de Revistas Científicas de América Latina, El Caribe, España y Portugal]. 2008. Scientific Information System RedALyC: Science that is not Visible does not Exist [Sistema de Información Científica RedALyC: la Ciencia que no se ve no Existe]. Toluca, Mexico: Universidad Autónoma del Estado de México, Facultad de Ciencias Políticas y Administración Pública.

Organization of Iberian-American States [OEI: Organización de Estados Iberoamericanos], and Iberic-American and InterAmerican Network of Science and Technology Indicators [RICYT: Red de Indicadores de Ciencia y TecnologíaIberoamericana e Interamericana]. 2009. Policies and Instruments in Science, Technology, and Innovation in Latin America and the Caribbean [Políticas e Instrumentos en Ciencia, Tecnología e Innovación en América Latina y el Caribe]. Buenos Aires: OEI, RICYT. Available online at:

http://www.politicascti.net.

Republic of Colombia. 2009. Law 1,286 that modifies Law 29 of 1990, transforms Colciencias into Administrative Department, and Strengthens the National System of Science, Technology, and Innovation in Colombia [Ley 1,286 que modifica la Ley 29 de 1990, transforma Colciencias en Departamento Administrativo, y fortalece el Sistema Nacional de Ciencia, Tecnología, e Innovación en Colombia]. 1,286.

Salmi, Jamil. 2009. The Challenge of Establishing World-Class Universities. Washington, DC: The World Bank. Available online at: http://documents.worldbank.org.

Salmi, Jamil. 2002. Higher Education at a Turning Point. In Higher Education in the Developing World. Changing Contexts and 
Institutional Responses, ed. by David W. Chapman, and Ann E. Austin (pp. 23-43). Westport, CT: Greenwood.

Schwartzman, Simon. 2002. Higher Education and the Demands of the new Economy in Latin America. Washington, DC: The World Bank.

Willinsky, John. 2006. The Access Principle. The Case for Open Access to Research and Scholarship. Cambridge, MA: Massachusetts Institute of Technology. 